\title{
Working Accidents among Mill Operators in Small-sized Factories Manufacturing Home Roof Tiles in Pejaten and Nyitdah Villages, Tabanan Regency Indonesia
}

\author{
SUTJANA, I.D.P. \\ Department of Physiology, Udayana University
}

\begin{abstract}
Working Accidents among Mill Operators in Small-sized Factories Manufacturing Home Roof Tiles in Pejaten and Nyitdah Villages, Tabanan Regency Indonesia: SUTJANA, I.D.P.: Department of Physiology, Udayana University-Hand presses and mills for making home roof tiles have been used since 1980 in small-sized factories in Pejaten and Nyitdah villages. While the mills have such advantages as shortening the production process, reducing the physical workload and decreasing dust, working accidents caused by using the machines have increased. In December 1996, the heads of two villages, the owners and the operators of the machines were interviewed and the factories were inspected to clarify the relationships between machine use and working accidents. The results showed that the frequency of the accidents was not high but the injuries were severe due to machines with no safety covers and a lack of knowledge in safe machine operation. (J Occup Health 2000; 42: 91-95)
\end{abstract}

Key words: Working accident, Mill operators, Home roof tile, Small-sized factory

In Indonesia the use of machines and mechanical tools has been widely adopted in all economic activities including the small-sized home roof tile factories in Pejaten and Nyitdah villages in Tabanan Regency $25 \mathrm{~km}$ from Denpasar city. Since 1980 hand presses and mills have been introduced to the factories in the two villages. The mills are used for mixing and crushing clay and sandstone. The use of mills has brought advantages such as shortening the production process, reducing the physical workload, and decreasing dust concentration in workplaces ${ }^{\prime \prime}$. On the other hand it has caused other problems such as noise, air pollution, and a high risk of accidents. Since the new mill operators had not been

Received June 26, 1998; Accepted July 17, 1999

Correspondence to: Sutjana, I.D.P., Department of Physiology, Udayana University, Denpasar, Bali, Indonesia trained before starting their job, they did not know which parts of the machine were dangerous. In view of these problems, a study was conducted on the mill operators in the home roof tile factories in Pejaten and Nyitdah villages to find out: 1 . The incidence of work accidents caused by using new machines and the accident risk factors. 2 . Operator's work load.

\section{Method}

The study was conducted in December 1996. According to the heads of Pejaten and Nyitdah villages, there were 82 mills and 567 hand press machines in these villages. The total number of workers was 1,384. Most of the workers came from Singaraja, Lombok and East Java. The highest education standard of the workers was senior high school but most had only elementary school education. Subjects surveyed were 2 heads of the villages, 10 owners, and 20 mill operators in Pejaten and Nyitdah villages. The anthropometric measurements for the mill operators in the two villages are shown in Table 1. The anthropometric data are not significantly different from those reported by other researchers ${ }^{2,31}$. Tasks and accidents during the last three years were the subject of interviews. The work process, work body posture and machine size were inspected, and heart rate during work were measured by ten pulse methods to evaluate work load.

\section{Results and Discussion}

\section{Types of mills}

There were two types of mills, namely, a stationarytype mill with a $20 \mathrm{HP}$ diesel engine used in larger factories (Fig. 1), and a mobile-type mill with an $18 \mathrm{HP}$ diesel engine and wheels (Fig. 2). The height of the inlet for raw materials and the height of the outlet of the stationary-type mill were $125 \mathrm{~cm}$ and $50 \mathrm{~cm}$, respectively, and those of the mobile-type mills were $147 \mathrm{~cm}$ and 85 $\mathrm{cm}$. The sound level of the former was $84.5 \mathrm{dBA}$, and the latter $84.5 \mathrm{dBA}$. 
Table 1. The anthropometric data for the mill operators

\begin{tabular}{lrr}
\hline & Male $(\mathrm{N}=12)$ & Female $(\mathrm{N}=8)$ \\
\hline Age $(\mathrm{yr})$ & $36.4 \pm 4.23$ & $33.6 \pm 4.56$ \\
Height $(\mathrm{cm})$ & $159.4 \pm 7.65$ & $156.5 \pm 5.64$ \\
Weight $(\mathrm{kg})$ & $50.1 \pm 4.75$ & $50.9 \pm 4.35$ \\
Shoulder height $(\mathrm{cm})$ & $134.6 \pm 2.35$ & $132.4 \pm 2.36$ \\
Elbow height $(\mathrm{cm})$ & $102.9 \pm 2.43$ & $99.2 \pm 2.12$ \\
Grip height $(\mathrm{cm})$ & $72.3 \pm 2.56$ & $70.5 \pm 2.32$ \\
Upward reach height $(\mathrm{cm})$ & $178.2 \pm 2.42$ & $173.5 \pm 2.91$ \\
Forward reach $(\mathrm{cm})$ & $65.4 \pm 2.32$ & $60.9 \pm 2.14$ \\
Side reach $(\mathrm{cm})$ & $62.8 \pm 3.21$ & $60.5 \pm 2.33$ \\
\hline
\end{tabular}

\section{Working process}

The raw materials, mixture of clay and sandstone (ratio 2:1), are moistened with water. The mix is lifted using a basket and poured into the inlet of the mill where it is rolled and crushed to form a dough and then pushed through the outlet as a block-shaped product. To speed up the process, one operator goes up to the inlet of the mill and pushes the raw material with his foot (Fig. 3a). The product is cut and collected near the mill. The mill is operated by 3 workers. Working time is from 07:00 to 15:00 with a lunch break from 12:00 to 13:00. The productivity of the stationary-type mill is $3500-4500$ pieces per day. Output of the mobile-type mill was dependent on the amount of raw material processed by the customers. In general, it is around $350-400$ pieces. It takes three to four days of manual pressing to form the roof tile, but in the milling process it takes only $30 \mathrm{~min}$.

\section{Working body posture}

As stationary-type mills have an inlet height of 125 $\mathrm{cm}$, it is easy to lift the raw material to them, but the outlet height is $50 \mathrm{~cm}$, so workers have to squat to collect the product. Because the mobile-type mills have an inlet height of $147 \mathrm{~cm}$, it is rather difficult to pour the raw material into it, having to lift it higher than shoulder height, but as the outlet height is $85 \mathrm{~cm}$, workers can collect the products with a natural body posture.

\section{Work load}

Measurement of heart rate was used for evaluating the workload during work by other researchers in Bali ${ }^{4-8}$. The average heart rate of operators who lifted $20-25 \mathrm{~kg}$ of raw material at the stationary-type mill inlet was 112.5 $\pm 2.45 / \mathrm{min}$, and that at the mobile-type mill inlet was $113 \pm 2.65 / \mathrm{min}$. The average heart rate of the operators who collected the product from the stationary-type mill outlet was $98.1 \pm 3.12 / \mathrm{min}$ and from the mobile-type mill outlet was $98.33 \pm 4.23 / \mathrm{min}$. There is no difference in operator's heart rate between the stationary-type and mobile-type mills.

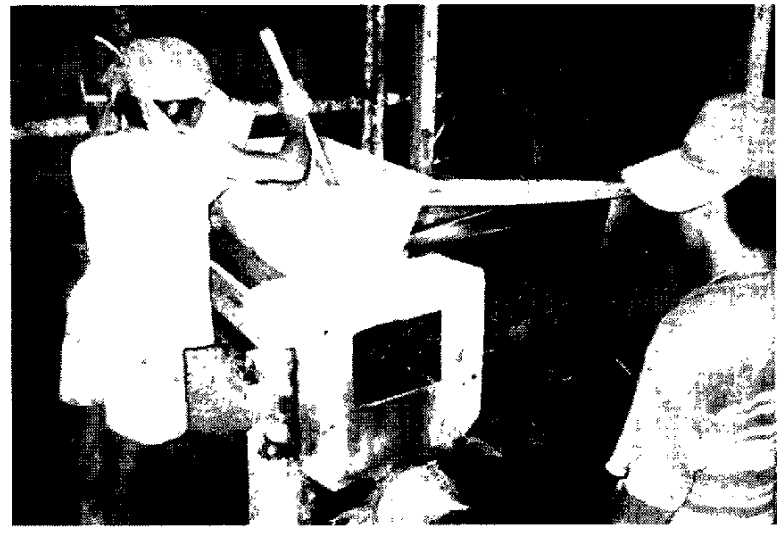

Fig. 1. Stationary-type mill.

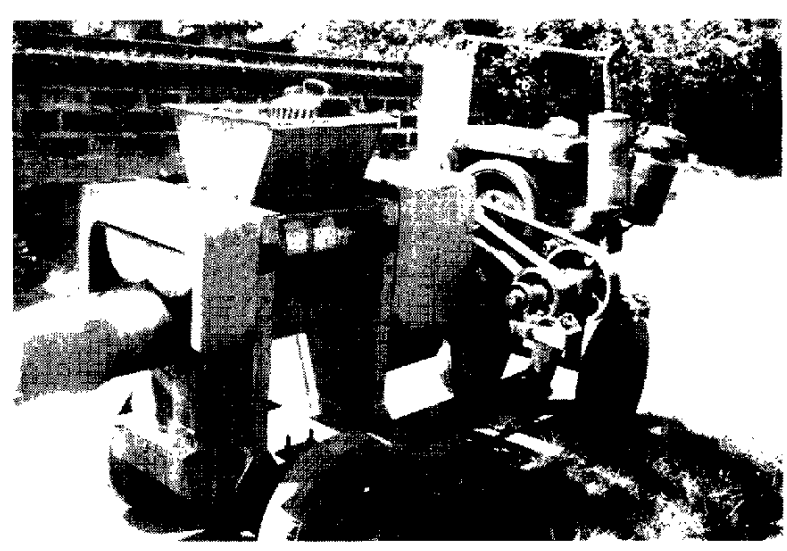

Fig. 2. Mobile-type mill.

\section{Incidence of accidents among mill operators during $1993-1996$}

Due to limited information and no record of injury accidents, it was very difficult to get the exact incidence information of working accidents among mill operators. The data analyzed in this study are only based on retrospective recollections of accident cases. The informants in this case were heads of the villages, owners of mills, and the mill operators who were injured. The accident cases varied from minor injuries to very severe ones. During 1993-1996, 31 cases were noted. Table 2 illustrates details of the cases. The incidence of mobiletype mill accidents was higher than that of the stationarytype mill accidents. Hand and foot accidents are more prominent. Even if the frequency of the accident cases seems to be small, the injuries were severe, for example, the loss of a hand or fingers (Fig. 4). Such physical defects caused a serious effect on workers' daily lives and social activities. There is no relationship between working body posture and incidence of accidents on either mobile-type or stationary-type mills. 


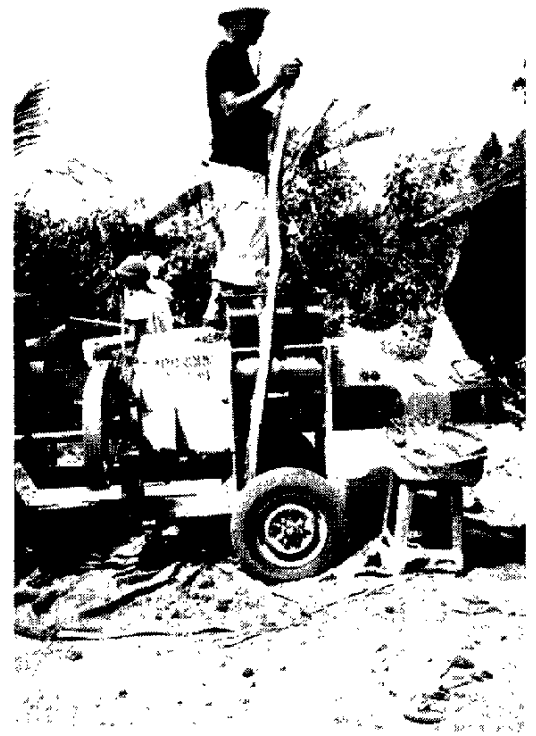

Fig. 3a

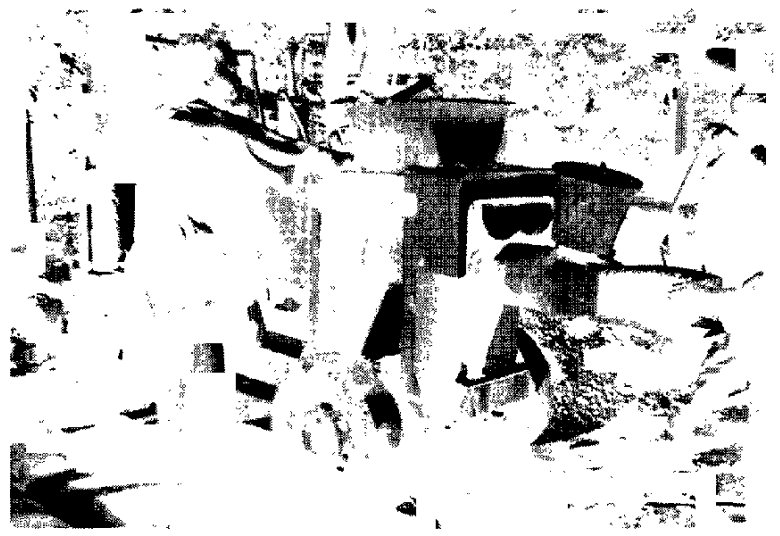

Fig. 3b

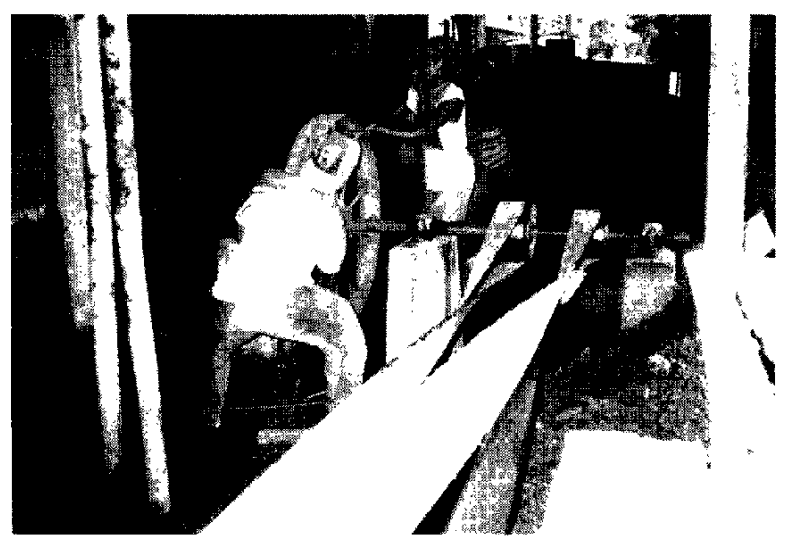

Fig. 3c

Fig. 3. Unsafe work and working condition. a: An operator goes up to an inlet of a mobile-type mill. b: An operator cleans rollers of a mobile-type mill. c: Pulley belts of a stationary-type mill with no safety cover.

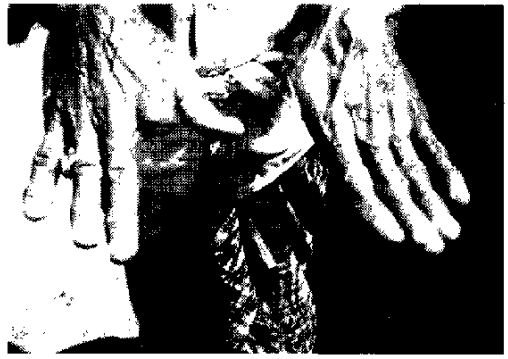

a

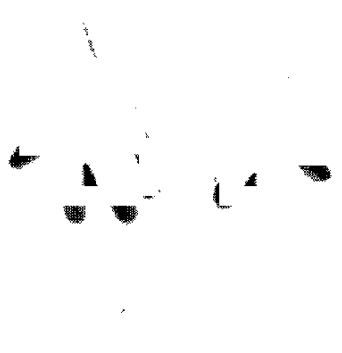

b

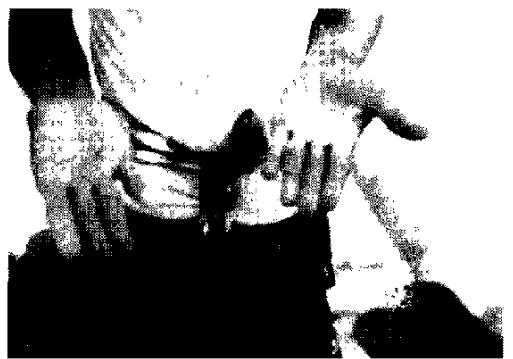

C

Fig. 4. Examples of finger injury. a: The right index finger severed. b: The left ring and little fingers severed. c: The right thumb severed.

\section{Accident analysis}

From the ergonomic point of view the work accidents could occur due to 3 factors: task, working organization and environment ${ }^{9}$ 10'. As for the tasks of mill operators, they did not patiently wait for the machine to deliver the product. As for the working organization, the operators were untrained and careless, and there were no clear job descriptions for the workers and often no proper schedules for operating the machines. As to the working environment, the machines were not equipped with proper safety devices, the workplaces were not well organized, and the operation area was not wide enough to work. 
Table 2. Cause and type of injuries

\begin{tabular}{|c|c|c|}
\hline type of injuries & $\mathrm{n}$ & $\mathrm{s} / \mathrm{m}^{*}$ \\
\hline \multicolumn{3}{|l|}{ 1) Caused by mill rollers } \\
\hline cut of toes & 4 & $\mathrm{~m}$ \\
\hline cut of heel & 4 & $\mathrm{~s}, \mathrm{~m}$ \\
\hline cut of first phalanx of hand & 5 & \\
\hline cut of thumb & 1 (Fig. 4a) & $\mathrm{m}$ \\
\hline cut of ring and little fingers & 2 (Fig. 4b) & $\mathrm{m}$ \\
\hline cut of index finger & 1 & $\mathrm{~m}$ \\
\hline bruise of finger & 2 & s \\
\hline \multicolumn{3}{|l|}{ 2) Caused by mill gears } \\
\hline cut of all fingers & 1 & $\mathrm{~m}$ \\
\hline cut of thumb & 1 (Fig. 4c) & $\mathrm{m}$ \\
\hline \multicolumn{3}{|l|}{ cut of thumb, index } \\
\hline and middle fingers & 2 & m \\
\hline \multicolumn{3}{|l|}{ 3) Caused by pulley belts } \\
\hline bruise of abdominal wall & 1 & s \\
\hline aberration of lower hand & 1 & $s$ \\
\hline bruise of buttock & 1 & $s$ \\
\hline bruise of finger & 3 & m \\
\hline 4) Caused by cooling fan & & \\
\hline bruise of finger & 3 & s \\
\hline
\end{tabular}

More specific factors relating to the accidents were as follow (Table 2):

1) Mill rollers: a) To speed up the process, the operator went up to the inlet of the mill and pushed the raw material with his foot. If the machine had no proper protective device, his toes or heel might enter the rollers, and at that time his foot would be crushed (Fig. 2). b) Sometimes a small stone became trapped between the rollers and the mill stopped. If a worker tried to remove the stone by hand without protection, his hand could be crushed between the rollers. c) After finishing the process, if a worker started to clean the roller by hand before the machine was turned off, his fingers might be crushed (Fig. 3b).

2) Mill gears: a) There were no safety covers around the mill gears. An operator sometimes pushed the gears by hand even if the mill was on, and the operator's hand (fingers or palm) could be crushed by the gears. According to Manuaba ${ }^{4}$, Grandjean ${ }^{11}$, and Biman ${ }^{12)}$, this type of accident is due to a reduction of workers' concentration during work. b) When the mill was being oiled by the operator, a receive pipe was sometimes pulled by the mill gears. The operator was startled and he put his hand in the mill gears and the hand crushed.

3) Pulley belts: Pulley belts of the stationary-type mill were running at high speed without any safety covers, which was dangerous for an ignorant operator (Fig.
$3 c)$.

4) Cooling fan of diesel engine: The cooling fan of the diesel engine was sometimes more dangerous. If an operator put his hand into the running fan, the hand would be cut.

5) Lack of knowledge : Other accident factors were ignorance and unsafe actions ${ }^{4}$. All parts of the mill can easily cause an accident when it is on, but workers' knowledge about safe machine operation was not enough to avoid the high risk of accidents due to the lack of training. Consequently new employees were the dominant victims of mill accidents. Beside that, they do not work with sufficient caution. This is very unfortunate, and the Minister for Man power is regularly campaigning for occupational health and safety working conditions.

\section{Insurance for work accidents}

Up to now there has been no accident insurance system in the two villages. It may be because the number of employees was less than ten persons. Employee insurance (ASTEK) covers enterprises with ten or more employees, or if the total amount of salary is one million rupiahs or more a month.

\section{Conclusions}

The following conclusions have been drawn from this study: (1) the incidence of accidents resulting in disability of workers was 31 during 1993-1996, (2) the incidence of mobile-type mill accidents was higher than that of stationary-type ones, and there was no relation between working body posture and incidence of accidents on either mobile-type or stationary-type mills, (3) major causes of the accidents were absence of safety devices on the mills, lack of knowledge of the workers about working methods and safety, and workers' insufficient caution, and (4) there is no insurance covering the workers at the two villages.

Therefore the following is recommended: (1) the mills be provided with safety devices, (2) training and supervision of the workers must be continuous, especially for new workers, and (3) work accident insurance for employees must cover all employees including the informal sectors.

\section{References}

1) Sutjana DP. Implementation of Wet Method Increasing of Roof Tile Home Industry Productivity at Pejaten Village. National Seminar of Indonesian Physiological Association. Surabaya, October 10-12, 1986 (in Indonesian).

2) Manuaba A, Sutjana DP. Anthropometric Data of Indonesian in Various Occupations. J Human Ergol, 1989; I8: 117-119.

3) Sena A. Improvement of Sitting Working Posture to 
the Subjective Felling and Productivity of 'Cagcag' Workers at Gelgel village Klungkung Regency. Postgraduate Tesis, Denpasar 1999.

4) Manuaba A. Health and Safety Work Implementation Based on Cultured Approach. Some Problems must be given more attention. One Day Seminar on Health and Safety Work implementation based on Cultured Approach. Denpasar, February 101992 (in Indonesian).

5) Tirtayasa K, Sutjana DP, Karna K. The Heart Rate Recording of Three Climbers of Batur Mountain. Udayana Medical Journal 1995; 25: 156-159.

6) Adiputra N, Suyasning HI, Sutjana DP, Manuaba A, Vanwontergem $\mathrm{K}$. The Workload of Traditional Harvesting Task. Udayana Medical Journal 1998; 29 : 150-153.

7) Adiputra N. The Workload of Modern Balinese Baris Dancing and Its Effects on Some Physiological Parameters. Doctoral Dissertation. Airlangga University, Surabaya.

8) Adiputra N, Sutjana DP. The Workload of Carrying
Cements in Benoa Harbour of Denpasar, Bali. Udayana Medical Journal 1997; 28: 32-37.

9) Manuaba A. Safety Design to Prevent Accident and Injury. An ergonomics approach. National Seminar on Community Intervention in Accident Prevention. Ciloto, West Java, November 20-22, 1989.

10) Manuaba A, Vanwontergem K. Improvement of Quality of Life: Determination of Exposure Limits for Physical Strenuous Tasks Under Tropical Conditions. Final Report. Dept. of Physiology School of Medicine Udayana University-Cergo International Brussels Belgium-The Commission of the European Communities Brussels, Belgium: 1996.

11) Grandjean E. Fitting the task to the Man. A textbook of Occupational Ergonomics. 4th Edition. Taylor \& Francis London, 1988.

12) Biman DAS. Advances In Industrial Ergonomics and Safety II. Proceeding of the Annual International Industrial Ergonomics and Safety Conference. Montreal Quebec Canada, June 10-13, 1990; 513-535. 